\title{
Problematising Development in Sustainability: Epistemic Justice through an African Ethic
}

\author{
Siseko Hudson Kumalo, Rhodes University, South Africa
}

\begin{abstract}
This paper critically engages with the concept of development through an analysis of epistemological justice in education for sustainable development (ESD) and presents alternative strategies for adaptation of the concept in the South. Many definitional challenges still surround development studies. The paper draws on the work of Wolfgang Sachs (1999) who asserts that the notion of sustainability has been consumed by development, presenting a view of sustainability which challenges the current and dominant economically driven hegemonic development discourse in which sustainability has become embedded. Further useful perspectives for this paper are offered by Amartya Sen (2001) who refers to development as a form of freedom. Sachs (1999) maintains that global definitions of development cement the dominant hegemonic discourse of the leading North, which has resulted in an obfuscation of the epistemological contribution from the South. The paper argues that, in the integration of congruent and enabling conceptual frameworks, allowing epistemic justice and validating the lived experience of learners through socially responsive pedagogical frameworks, South Africa is beginning to respond to the global environmental crisis. At the core of the paper is the question of whether an African ethical position advances the attainment of sustainability objectives. The paper concludes by positing a shift in scholastic and social understandings of development, and redefining the term from a changing terrain which may seem immutable with the current environmental crisis.
\end{abstract}

Keywords: Epistemology, development, pedagogy, justice, African ethics.

\section{Introduction}

At the core of problematising development lies the question of defining and critiquing the term. In extending the definition, this paper draws on Sachs (1999), a developmental theorist who critiques Western (Anglo-American and European) ideas of development and Sen (2001), who writes from an economic position. Both scholars are drawn on in this paper for questioning epistemic justice.

In incorporating an African ethic into sustainability discourse, the question of epistemic justice is most appropriate as a starting point in the debate of sustainability and epistemology. Locating this discussion in a decolonial theoretical framework (Grosfoguel, 2013), evoking an African ethic in sustainability, there is a need to first define an African ethical position. Prior 
to critiquing development, or extending the definition as considered by the arguments of both scholars who will be discussed in this paper, the link between epistemic justice and sustainability needs to be clarified. Arguing for epistemic justice that is substantiated by an African ethical framework will underscore the link between the two.

Clarifications on epistemic justice will serve the purpose of advancing the role of an African ethic in producing a critical citizenry which understands the moral obligation in meeting sustainability goals. Using a reflective understanding of the Eco-Schools programme (with my own experience of it), interactive models of teaching and learning are explored as the premise for the argument in this paper, which demands epistemic justice in defining development.

The need to fully exhaust the debate of epistemic justice from an African ethical position will become clear, through making the link between sustainability and epistemology as a point of discussion. To substantiate Sachs's position, who argues 'that development is the never ending race' (1999:29), understanding 'modernity as synonymous with colonialism' (Grosfoguel, 2007:218) is of fundamental importance. An African ethical position and its use in the sustainability discourse should thus be understood in two parts: 1) as a shift from the universal conceptions of development; and 2) as creating an ecology of knowledges which is a 'constitutive part of the pluriversity' (Grosfoguel, 2012:2).

This paper posits that epistemic justice arises as a response to the call from the decolonial theoretical position (Grosfoguel, 2013) for alternative conceptions of development and modernity, one which necessitates a conceptual shift in understanding education for sustainable development (ESD) through the use of an African ethic. In texturing the conceptual critique in this paper, Sen's (2001) capabilities approach (with specification to capabilities deprivation, conceptualised in this argument as epistemic injustice) will be considered for the purpose of extending the definition of development. Capabilities deprivation, understood as the privileging of Western conceptions of modernity, leads to epistemic injustice, highlighting the dialectical relationship between epistemic injustice and capabilities deprivation. The dialectic here being the privileging of Western definitions of development as the thesis, resultant capabilities deprivation as the antithesis, and epistemic injustice as the synthesis - thereby revealing the interactive relationship between epistemic injustice and capabilities deprivation. This paper raises key problematics in Western ideas of equating development with progress, and highlights the tensions between progress and sustainability. The paper seeks to resolve this tension by broadening the definition of development, using the capabilities approach as proffered by Amartya Sen. This is in line with the 'architectonic capability' argument advanced in the work of Le Grange (2012a:139). Le Grange argues that ubuntu/ukama (informed by an African ethic) 'can be seen as an architectonic capability, as it gives rise to the realisation of other capabilities' (2012a:143). Ukama, as explored by Le Grange, denotes an African moral principle derived from the Shona language and means 'interconnectedness with the universe' (2012b:62). From this definition, developed through an analysis of language (Shona, isiXhosa and isiZulu), the parameters of an African ethic become more apparent, making the task of setting up an African ethical position attainable.

At the core, this paper seeks to posit how epistemic justice, defined from an African ethical position, upholds and advances the attainment of sustainability objectives. 


\section{Defining an African Ethical Position}

Ramose defines ethical responsibility as acting to 'promote life and avoid killing' (2014:68) while further substantiating that this ethical position should meet the criteria of acknowledging the living and the living-dead, while leaving the land as good as we found it (2014:75). This, he argues, meets the African understanding of community, which necessitates 'an overall obligation towards the living - which can otherwise be articulated as human beings, plant and animal kingdoms - the living-dead, or ancestors, who continue to live with us and leaving the land as good as we found it' (2014:75). A moral obligation to the community implies that which allows one to truly 'realise personhood in caring not only for themselves but also for the others' (Le Grange, 2012c:333). The assertion of a moral obligation towards others, which should not be 'limited to human life, but extended to the natural environment' (Le Grange, 2012a:143), re-inscribes the African ethical definition of community as outlined by Ramose (2014). It is clear how the 'architectonic capability' (Le Grange, 2012a:139) can be understood as epistemic justice, through recognising an African ethical position and incorporating this ethic within the sustainability discourse as it has framed the historical responses of African communities of southern Africa to their natural environments. The 'architectonic capability', as coined in the work of Le Grange (2012a:139), begins the discussion which seeks to broaden the definition of development.

The conception of the ethical position presented in this paper shifts away from a communalism conception of personhood, which looks at the 'relationship between the individual and the community while linking this relationship to morality, moral thought and reasoning' (Ikuenobe, 2006:51). The caution against conceptualising this ethical position as a form of communalism or humanism is aptly articulated by Le Grange, who quotes from Ramose, "humanness [...] is thus opposed to any "-ism", including humanism, for this tends to suggest a condition of finality, a closedness or a kind of absolute either incapable of, or resistant to, any further movement' (2012b:63). This limitation is once more raised by Ramose, in response to Metz, as Ramose rejects an attempt to mould African morality and ethics into a Western conception. He states:

Wiredu, and Bujo, including many other African philosophers do not speak to Metz's conception of 'normative theory' as 'articulation and justification of a comprehensive, basic norm that is intended to account for what all morally right actions have in common as distinct from wrong actions'. On the contrary they speak to a multiplicity of ethical principles that found and permeate African morality without any implicit or explicit claim to immutability, essentiality or eternity. (Ramose, 2007:351)

A distinction should therefore be made between 'ethical' and 'moral' African positions which would seek to clarify the differences between Ramose (2014) and Ikuenobe (2006). Articulating an ethical responsibility or obligation, Ramose seeks to propose a sense of reasoning which defines our actions in what he terms 'right reason' (Ramose, 2014:75) underscored by justice; while Ikuenobe could be understood to be articulating moral obligation from an internal 
truth perspective, which demands the ethical as the juridical adjudicator in the clash between conflicting internal truth positions. In this adjudication, the ethical becomes the forebear of justice, as both positions of conflicting internal truths will be judged against reason, premised on what is ethically just. Right reason, in the juridical system used in mediating between conflicting internal truth positions, is to be understood in this argument as that which is justly fair.

Ikuenobe's conception of personhood, which is linked to a 'communalism definition of the self' (2006:52), extends Ramose's argument (though differing in its presupposition of communalism) 'through a recognition of the collective community as a constitutive part of the self' (2006:75), stressing the first two elements of social responsibility and ethical obligation noted as regarding: 'the living' and 'the living-dead' (Ramose, 2014:75). The third prescriptive element of the ethical position, defined by Ramose as 'leaving the land as we found it' (2014:75), can be understood as social responsibility that is a 'constitutive part of personhood' (Ikuenobe, 2006:52). This element supports Le Grange's claim, which highlights the three ecologies otherwise known as 'self, social and nature' (2012b:57).

Moving away for a moment from the philosophical framework used in developing this argument, the constituent parts of personhood can otherwise be taken to mean homoeostasis. Homoeostasis in the ecological sciences is understood to be that which is whole, with individual parts serving the purpose of 'self-regulating feedback mechanisms which maintain the whole' (Sachs, 1992:31). Once more, the concept of homoeostasis substantiates the argument of Le Grange (2012b:59), who notes that the effect, be it negative or positive in one category, will inherently influence the other categories within the three ecologies. The argument of homeostasis therefore can be understood as underscoring the ethical obligations set out in Ramose's argument, which demands that we 'leave the land as we found it' (2014:75) as this serves the purpose of supporting life for future generations - an argument rooted in an African ethical position.

Defining this as an African ethic demonstrates how this moral and ethical position moves away from individualistic reasoning claimed by the autonomous agent affirmed by Descartes's cogito claim, 'I think therefore, I am' (Grosfoguel, 2007:214). Later, this paper will consider the power of this claim that has been used in dismissing African ontologies, leading to epistemic injustice, otherwise termed 'epistemicide' (Grosfoguel, 2013:73). Using an African ethic demonstrates the intrinsic relation between the individual and the ecological, highlighting the ethical and moral obligations for a collective existence which speaks to realising sustainability objectives. If the conceptual framing of interactive teaching models recognises the individual as constituted by collective community and ecological components, social responsibility becomes imbued in pedagogical practices. Pedagogies of social responsibility substantiate Ramose's requirement to leave the land as we found it (2014).

\section{An African Ethic and Epistemic Justice}

Understanding local knowledge and indigenous knowledge systems (IKS) within the framework of an African ethic is critical to the argument being advanced in this paper. Writing from a position advocating for the integration of IKS into university curricula, Magara notes 
the 'particularity and specificity of indigenous knowledge to a geographical locale' (2015:25). To fully realise the objectives of this paper as set out in the introduction, Magara's definition needs extension, with clear limitations which caution against an essentialist understanding of IKS and which are underpinned by an African ethic.

Local knowledge can be understood as that which is particular, site-specific and determined by the locale. IKS, conversely, specifically regarding the southern African sustainability discourse, should be evaluated against the ethical position that denotes a moral obligation to leave the land as we found it, in order to meet the criteria of being defined as an IKS. The move of locating IKS in an African ethic suggests a limitation on any knowledge system from being seen as indigenous to Africa. The inclination towards the African ethical proposition discussed above connotes a personhood rooted in social responsibility as a constitutive part of that personhood, therefore allowing for southern African knowledge systems to be viewed as indigenous on the premise of espousing a moral obligation. Indigeneity in knowledge systems must be understood to include variations in local knowledge, substantiating Ramose's claim of 'different internal truth positions' (2014:70). Further, the differing internal truth positions make room for the continuously growing, changing and becoming, which is embedded in ubuntu as a humanness.

Navigating the difference in 'internal and external truth, which constitutes reality for a given individual' (Ramose, 2014:68), the question of epistemic justice arises in the oppressive ontological denial masquerading as universal truth, as articulated in Western positions. Grosfoguel problematises the hegemonic power of 'Western countries being the leading voices in constructing the realities of the rest of world' (2013:87).

The Truman doctrine of underdevelopment, initiated in 1949, subsequently led to the 'never ending race of development' (Sachs, 1999:30) and underscores the notion of epistemicide as argued by Grosfoguel (2013). Understanding epistemicide in African ethics requires a consideration of inherent power relations in the knowledge-production process. Almeida looks at the epistemology discussion from a race-based perspective and critiques the exclusion of Oriental/indigenous knowledge on the premise of its 'experiential as opposed to empirical underpinnings' (2015:82). This exclusion can otherwise be seen as an existence which serves to validate Western civilization (2015:82). Through privileging Western epistemes by defining progress as 'developmental goals, judged on economic growth rates, Gross National/Domestic Product (GNP/GDP) rates' (Sachs, 1999:32), ecological concerns are obfuscated if not entirely erased from the sustainability discourse, along with any contributions from indigenous knowledges which may respond to the ecological crisis using alternative epistemic frameworks.

In playing what Sachs terms 'the catch up game' (Sachs, 1999:30), the developing world assumes the role Almeida talks about (2015), which is that of validating Western civilizations. Grosfoguel (2007) aptly demonstrates how the language of deficits continues to trap the indigenous subject in a constant colonial paradigm which began in the 16th century 'with the colonial subject as having no language', continued in the 18th and 19th century as having 'no history', and in the 21st century, 'no democracy' (2007:214).

Epistemic justice clearly illustrates the need for an African ethic in suggesting ecological solutions, taking into consideration the ontological position of the African subject. To 
illustrate this effectively, Martin, who speaks from a decolonial theoretical position, makes the claim that 'African social organisation models, ethics and politics were never in English, Portuguese, Spanish or French' (1992:49). Martin's argument is nuanced by Mkandawire's assertion illustrating gatekeeping, 'which privileges Western researchers, even on matters of local policy development on the continent' (1997:28). Appealing once more to epistemic justice, while working towards formulations which seek to advance the sustainability agenda, the incorporation of African ethics in response to the current ecological crisis could be termed appropriate and necessary.

Using interactive teaching models demonstrated in the work of the Eco-Schools project, - which looks at acknowledging the specificity of location while responding meaningfully to the ecological challenges of that specific locale - epistemic justice becomes imbued in teaching and learning practices. Through inculcating social responsibility fostered by interactive teaching models, rooted in an understanding of personhood as a constitutive part of the broader community as advanced in an African ethic as the starting point, there is a clear link between epistemic justice and sustainability. Sustainability is therefore derived from social responsibility inherent in an African ethic and which, when recognised, begins to deliver on epistemic justice. Justifying the sustainability discourse in this way creates room for recognising different social organisation models that are not premised on development as defined from an economic understanding that continues the language of deficits, if a society does not meet the development standards as defined by the Western world. However, one would need to qualify why a response to the ecological crisis would use this approach to sustainability as opposed to the propositions which have been proffered by Western modernity.

Having explained the limitations of Western modernity (as a trapping which continues to highlight deficits in the Oriental/indigenous subject, and manifesting as a neo-colonial ordering of the contemporary world, what Le Grange terms 'Integrated World Capitalism' [2012b:57]), further articulations prove the need to redefine our conceptions of sustainability and development. Esteva, a developmental theorist, points out how 'contemporary understandings of development elucidate the deficit discourse and continue to subjugate the indigenous body' (1992:8). Further to this, Western conceptions of the sustainability discourse alienate and remove the socio-cultural specificities in sustainability, reinforcing the need to make economic development sustainable, which should be understood as a fundamental contradiction in the pursuit of a more sustainable future. This approach to sustainability has its origins in the first attempt at an internationally cohesive effort towards mitigating environmental degradation - notably, the Brundtland Report, otherwise known as our Common Future (1987). In the process of mitigation, sustainable development has come to mean a form of 'managerialism of the environment' (Sachs, 1999:33), with cybernetics used in the homoeostasis conceptions of the world as a means of exercising dominion over the environment through cybernetic manipulation or regulation.

In approaching the development debate from a position which divorces human interaction from ecology, but which rather assumes a management strategy for dealing with key challenges facing the imminent threat of global climate change, Grosfoguel's 'sub-zero position of the God-Knower' (2007:213) begins to reveal the implications of colonialism. This position 
explicates two fundamental tenets of this argument. Firstly, the sub-zero Eurocentric perspective is the focal point for creating universalisms which silence indigenous ways of knowing by proffering solutions couched in universality when, in fact, they themselves are provincial ways of knowing. Secondly, this position assumes the God-Knower perspective, which alienates humanity from the environment, and removes the African ethic in understanding personhood as a constitutive part of the third element of Ramose's definition, which is that of 'leaving the land as we found it' (2014:75). In removing the third element of the ethical definition, cybernetic manipulation, masquerading as homoeostasis management, undermines a genuine commitment to sustainability and thus allows the developmental agenda to continue unchecked and dressed-up in a new coat.

The first tension presented by the sub-zero position presents another challenge, which is that of the power relations inherent in the knowledge-production process. In acknowledging the provinciality of an African ethic, the sub-zero position dismisses any contributions which could be proffered as peripheral. The act of peripherising continental/provincial positions highlights the endemic epistemological injustice of the contemporary world order, while taking us back to the claim that 'African social organisation models, political organisation and economic principles were never articulated in English, French, Portuguese or Spanish' (Martin, 1992:49). In the act of defiance through challenging the Western definitions of development, there is the continual gating of the indigenous subject, what Esteva (1992:8) calls the 'pathologising, anomaly and unnatural behaviour' (as termed by the West) in not following unilinear conceptions of development.

Through the pathological ascriptions given to states which do not follow the Western modes of development, wa Thiong'o (1993:51) calls our attention to the use of 'economic and political control invariably leading to cultural domination'. Cultural domination understood as epistemic injustice cannot, thus, be escaped with the constant totalitarian hegemonic ideas of development which still permeate globally. Calling for a shift in such a conceptual understanding of sustainable development is premised on the need for epistemic justice as a means to effectively deal with the ecological crisis facing us today. However, the economic and political control articulated by wa Thiong'o (1993) cannot be divorced from the concerns raised by Mkandawire (1997:28) earlier in the paper, which speak to the gatekeeping stance taken by policy developers and the African state in privileging the voice of Western researchers and academics, even in matters of local policy development.

Sustainability obfuscated by development presents the discourse on ecology with a multitude of challenges which need attention. Fundamentally, development can be understood as a tension between sustainability and the course towards economic growth and expansion. Forever attempting to escape the connotations of being termed underdeveloped, lacking and deficient (Esteva, 1992:7), third world economies constantly strive for the economic growth rates of Western countries while neglecting the reality of the unsustainable nature of rapid growth and economisation. Other than the unsustainability of economisation, there is a further neglect, one which links this process of 'development with colonisation' (Esteva, 1992:17).

To resolve the tension between development and sustainability, the work of Amartya Sen can be of use to this argument. Looking at development through the lens of capabilities, 
which can be defined as 'political freedom, social opportunities and protective security' (Sen, 2001:10), allows for the flourishing of individuals in any given society, and thus substantiates the term 'development'. Political freedom may be defined as the opportunity to participate in constructing social policy and defending individual rights, which can only be fully actualised in a social context that recognises the individual as a constituent part of society. Enabling factors such as social opportunities (access to education, health-care) and political freedom, allow the individual to live their desired life. Protective security speaks to a social environment which does not bring harm to the individual in their pursuit of these enabling factors. Fundamental in the realisation of these capabilities, however, is the notion of the architectonic capability, understood as ubuntu (Le Grange, 2012a:139), framed and informed by an African ethic.

It is imperative to understand the interactive relation amongst the capabilities stated earlier. Deprivation of these capabilities is a denial of access to the three elements, and priority should be given to the social opportunities (attainment of an education, access to medical facilities and freedom of trade) which allow for the full actualisation of political freedom and protective security. Social opportunities, with the advancement of society through education, introduce the concept of development without tensions in relation to sustainability.

Sen's (2001) conception of development is not underpinned by rigid economic assessments of GNP/GDP and economic growth rates, and can thus can be viewed as an enabling model in understanding development. It is enabling in that it allows for the provincial definitions of societal advancement to be actualised using contextual interpretations of what development may look like. From this position, sustainability linked to social advancement in the attainment of these capabilities speaks to epistemic justice, in the contextual definitions proffered in consideration of solutions, which may be used to advance the sustainability agenda within a given locale.

The tension between development and sustainability can be resolved by proffering solutions which are based on an understanding of what is most pressing within each context in relation to the current ecological crisis. Using different epistemic positions not only allows for epistemic justice, but, through a site-specific ecological education that also responds to international demands, also allows for a more sustainable use of the human commons.

\section{Interactive Models}

Interactive teaching and learning models, briefly introduced in this argument, are fundamental to a model of ecological education that is site-specific while teaching from a position seeking to respond to the international challenge for more sustainable uses of the global commons. The Eco-Schools project, through its environmental education programme, not only integrates environmental education across the school curriculum, but further calls for practical learning. Taking the discussion on the ecological crisis outside of the classrooms and investigating local challenges (such as river acidification, sustainable water consumption, and the recycling of greywater within the school - Maritzburg College), all point to the use of contextual knowledge in responding to the ecological crisis.

Interactive teaching models which look at the everyday impact of our consumption patterns and their effects on the environment, bring the discussion of the African ethical 
position back into the debate. Personhood, constituted by the third element (Ramose, 2014:75), is exemplified in the interactive teaching models advanced above.

Social opportunities can also be recognised as the underpinning component of this form of teaching and learning. Without these social opportunities in education (advocated in this paper as interactive teaching methodologies, otherwise known as capabilities deprivation), development cannot be actualised. This use of the term 'development' can be clarified as: development defined outside the scope of rigid economic measurement instruments such as GDP/GNP and economic growth rates, but rather looking to the Human Development Index (HDI). A concession should be made in this argument to recognise that the use of the HDI itself may have shortcomings, in that it is defined from a Western perspective; however, as used in the work of Sen (2001), there is more room to navigate the definitions of development.

Invoking the African ethic obliges the debate on development to start with the recognition of how African social organisation, political theory and legal frameworks are written from the African position. Criticality is therefore necessary in formulating African articulations of development which are neither romanticised nor distorted in an arrested conception of what the African position may be. Mbembe, writing from a post-colonial theoretical perspective, notes the need for a differentiation between the 'traditional and fictive conceptions of the African subject' (2002:257). It is at this juncture that criticality must be deployed when formulating African ideas, so as to move away from essentialist arguments and understanding of what an African ethic in sustainability may be. While noting this caution as given by Mbembe (2002), it is also fundamentally important to note how Western modernity has appropriated elements of African thought, qualifying the argument made by Ramose which necessitates 'a critical explication of Western modernity acknowledging the contributions of African thought in advancing certain areas of Western civilisation' (2014:72).

\section{Conclusion}

Understanding the African ethical position which speaks to social responsibility and an ethical obligation as defined by 'a) the recognition of the living, b) the living-dead and c) leaving the land as we found it' (Ramose, 2014:75), has been the premise of this argument. From this position, epistemic justice has been argued for in the advancement of the sustainability agenda, taking into consideration the different epistemic positions which are dismissed by the Western hegemonic conceptions of development while arresting the attainment of sustainability objectives.

The tension between sustainability and development has been examined through showcasing how development envelopes sustainability, and is used to manage the continued objectives of development, economisation and subsequently colonisation in a new form. Economisation and colonisation have been argued against from a position of epistemic injustice that negates the ontological existence of the African/Oriental subject and uses the development discourse to validate Western civilisations (Almeida, 2015).

Explicating the problematics of development in the sustainability discourse has been used to showcase how continued epistemic injustice masquerading as Western 
universalisms perpetuates a degradation of the natural environment. Western countries have responded to the ecological crisis with a managerial strategy that assumes 'the sub-zero, God-Knower position' (Grosfoguel, 2007:214) and cloaks the manipulation of cybernetics for the purpose of managing homoeostasis. Clear distinctions have been made between this approach to the current ecological crisis and the African ethical response.

Attempting to resolve the tensions between sustainability and development, this paper has put forward a more inclusive definition of development, one which looks at the capabilities approach as argued by Sen (2001). Capabilities rooted in interactive teaching methodologies, illustrated by a short exploration of the Eco-Schools programme, locates the argument in the African ethical position of 'leaving the land as we found it' (Ramose, 2014:75).

\section{Notes on the Contributor}

Siseko Hudson Kumalo is reading for his Honours in Philosophy and Political \& International Studies at Rhodes University, South Africa. His research explores highereducation transformation in South Africa. He currently heads up the Decoloniality Higher Education South Africa (HESA) Project and Chairs the Philosophical Society of South Africa's (PSSA) Working Group on Transformation.

\section{References}

Almeida, S. (2015). Race based epistemologies: The role of race and dominance in knowledge production. Wagadu, 13(1), 79-105.

Esteva, G. (1992). Development. In W. Sachs (Ed.). Development dictionary: A guide to knowledge as power. London: Zed Books. (pp. 6-25)

Grosfoguel, R. (2007). The epistemic decolonial turn: Beyond political-economy paradigms. Cultural Studies, 21(2), 211-223.

Grosfoguel, R. (2012). Introduction: From university to pluriversity: A decolonial approach to the present crisis of Western universities. Human Architecture: Journal of the Sociology of SelfKnowledge, 10(1), 1-6.

Grosfoguel, R. (2013). The structure of knowledge in westernised universities: Epistemic racism/sexism and the four genocides of the long 16th century. Human Architecture: Journal of the Sociology of Self-Knowledge, 11(1), 73-90.

Ikuenobe, P. (2006). Philosophical perspectives on communalism and morality in African traditions. London, Boulder, New York, Toronto \& Oxford: Lexington Books.

Le Grange, L. (2012a). Ubuntu as an architectonic capability. Indilinga: African Journal of Indigenous Knowledge Systems, 11(2), 139-145.

Le Grange, L. (2012b). Ubuntu, Ukama and the Healing of Nature, Self and Society. Educational Philosophy and Theory, 44(2), 56-67.

Le Grange, L. (2012c). Ubuntu, ukama, environment and moral education. Journal of Moral Education, 41(3), 329-340. 
Magara, E.C. (2015). Integration of indigenous knowledge management into the university curriculum: A case for Makerere University. Indilinga: African Journal of Indigenous Knowledge Systems, 14(1), 25-41.

Martin, D.C. (1992). Out of Africa! Should we be done with Africanism? In V.Y. Mudimbe (Ed.), Presence Africaine and the Politics of Otherness (1947-1987). Chicago and London: University of Chicago Press.

Mbembe, A. (2002). African modes of self-writing. Public Culture, 14(1), 237-273.

Mkandawire, T. (1997). The social sciences in Africa: Breaking local barriers and negotiating international presence. The Bashorun M.K.O. Abiola Distinguished Lecture presented to the 1996 African Studies Association Annual Meeting. African Studies Review, 40(2), 15-36.

Ramose, M.B. (2014). Dying a hundred deaths: Socrates on truth and justice. Phronimon, 15(1), 67-80.

Ramose, M.B. (2007). But Hans Kelsen was not born in Africa:A reply to Thaddeus Metz. South African Journal of Philosophy, 26(4), 347-355.

Sachs, W. (1992). Environment. In Sachs W. (Ed.), Development dictionary: A guide to knowledge as power. London: Zed Books. (pp. 26-37)

Sachs, W. (1999). Planet Dialectics: Explorations in environment and development. London: Zed Books Sen, A. (2001). Development as freedom. Oxford and New York: Oxford University Press. wa Thiong'o, N. (1993). Moving the centre: The struggle for cultural freedom. London: James Curry. WCED (World Commission on Environment and Development). (1987). Our common future. http://www.un-documents.net/our-common-future.pdf, visited 3 January 2017. 